\title{
Political considerations in the protectionism against the transition economies
}

\author{
Jai S. Mah*
}

\begin{abstract}
This paper examines the effectiveness of the social and political factors as the determinants of antidumping duties against the transition economies. The empirical evidence shows that protectionist pressures tend to be strengthened against them with low labor standards, although protectionist tendencies with respect to social dumping are not so apparent in actual impositions of antidumping duties. There is a weak evidence that the different degrees of democraticness influenced the protectionism against the transition economies during the late 1990s, while such an effect is not found during the period of 2002-2006, as the concerned countries passed the initial stage of transition.
\end{abstract}

Keywords: protectionism, antidumping duties, political considerations, transition economies.

\section{Introduction}

The average tariff rates of most countries have been reduced substantially with several multilateral trade negotiations over the past half century. The reductions in tariff rates have led many of them to resort to discriminatory remedial measures like impositions of antidumping duties. Although many antidumping-related provisions were consolidated into the Antidumping Code of the WTO in 1995, antidumping duties have been so widely used that they may nowadays be regarded as the typical trade protection measures under the WTO system. Furthermore, investigations of antidumping cases by themselves tend to be perceived as protectionist pressures.

The current international trade regulations include provisions allowing the importing countries to investigate and impose the antidumping duties against the exports of the transition economies for 
social or political considerations. Authors such as Finger et al. (1982), Moore (1992), Baldwin and Steagall (1994), Hansen and Prusa (1996), Leidy (1997), Mah (2000a), Lee and Mah (2003), Nielsen and Rutkowski (2005), and Prusa (2006) tried to reveal the determinants of antidumping duties. However, they did not consider the social and political factors such as labor standards and different degrees of democraticness as the determinants of antidumping duties. Although for the past several years lots of antidumping duties were directed against the exports of the transition economies, there have been only a few papers that have tried to reveal their determinants, for instance, Nielsen and Rutkowski (2005). Therefore, this paper examines the effectiveness of such social and political factors as the determinants of the antidumping duties against the transition economies.

The remainder of this paper is organized as follows. In the next section, institutional characteristics of the antidumping duties against the products exported from the transition economies are explained. In sections 3 and 4, the model and empirical evidence are presented. Conclusions are provided in section 5 .

\section{Institutional characteristics of the antidumping duties against the transition economies}

The GATT Article VI has allowed the contracting parties/Members of the GATT/WTO to take discriminatory, remedial measures such as antidumping duties under certain conditions. For imposition of antidumping duties, there are three basic conditions to be satisfied: first, the existence of dumping margin which is defined as the difference between normal value and export price; second, material injury to concerned domestic industries; and, third, causal relationship between dumped imports and material injury to domestic industries. In case that these conditions are met, the importing countries can impose antidumping duties.

Since the inauguration of the WTO system in 1995, about three out of ten cases relating to antidumping duties have been focused on the transition economies. Although we can also consider impositions of countervailing duties as the discriminatory protectionist measures, they are not applicable to the transition economies in many countries including the United States which has led imposition of countervailing duties. Therefore, the protectionism against the transition economies can in general be equated with impositions of antidumping duties.

Investigations or impositions of the antidumping duties against the transition economies have the following institutional characteristics. First, the margin of dumping in respect of the product exported from the transition economies may be determined by a method different from one applied to the products exported from market economies. In calculating the margin of dumping, it is needed to know the data for normal value. Although domestic price is usually used as the measure of normal value, in case of the transition economies many of which are still influenced by the central planning, it may be quite difficult to get the relevant data, since cost and prices may not be fully determined by market forces. The special problem of establishing comparable prices in the 
case of a centrally planned country was noticed even in the 1950s (Polouektov, 2002).

Reflecting the difficulties in the calculation of dumping margin concerning the export of the centrally planned economies, note 2 in paragraph 1 of Ad Article VI of the GATT stipulated: "It is recognized that, in the case of imports from a country which has a complete or substantially complete monopoly of its trade and where all domestic prices are fixed by the State, special difficulties may exist in determining price comparability for the purposes of paragraph 1 , and in such cases importing contracting parties may find it necessary to take into account the possibility that a strict comparison with domestic prices in such a country may not always be appropriate." Therefore, it is usually needed to derive the constructed value in calculating the margin of dumping of the dumped products exported from the transition economies. The problem is that it is in many cases arbitrary to construct normal value of the concerned product.

In the United States, for instance, the Department of Commerce (DOC) resorts to provisions designed specifically to deal with the special problems of non-market economy countries, including provisions for the calculation of normal value for nonmarket economy country exports. In situations where the DOC cannot determine normal value through the usual methods provided for in section 773(a), it determines the normal value of the good by valuing each factor of production that goes into making the good based on the values of those factors in a market economy country. The market economy country, or surrogate country, chosen by the DOC would be one that (1) produces a significant amount of similar merchandise, and (2) is at a comparable level of economic development (Laroski, 1999). Meanwhile, choosing such countries may be determined arbitrarily.

Second, while the concerned transition economies designated as non-market economies obviously affect antidumping decisions, such designations may be influenced by political considerations. For instance, according to section 771(18)(A) of the U.S. Tariff Act of 1930, the term 'non-market economy' includes any foreign country that the DOC determines "does not operate on market principles of cost or pricing structures, so that sales of merchandise in such country do not reflect the fair value of the merchandise." The fact that the determination is not subject to judicial review gives the impression that the non-market economy determination is a political determination rather than a predictable and methodical one (Laroski, 1999).

Third, regarding the initiation of a petition for antidumping duties, Article 5 of the Antidumping Code of the WTO stipulates that a petition must be filed 'by or on behalf' of the industry. However, note 14 of the Antidumping Code has implications for the provisions on initiating an investigation. This note states that in certain Members' territories, employees of domestic producers of the like product or representatives of those employees may make or support an application for an investigation. The problem with this is that it creates the opportunity for trade unions or their representatives to file petitions alleging dumping and injury to a domestic industry. Potentially, this is the introduction of a social clause which can restrict the capacity of the developing countries to penetrate the markets of the developed countries in particular (Kufuor, 1998).

The debate over social dumping which can be defined as the alleged use by companies or countries of low labor standards to compete unfairly against other companies or countries which offer higher labor standards and thus have higher costs has been one of the most divisive debates in international trade (Evans and Walsh, 1995). Article 7 of the Havana Charter which was expected 
to be the Constitution of the inborn International Trade Organization in 1947 took the possibility of social dumping into consideration, saying: "The Members recognize that unfair labor conditions, particularly in production for export, create difficulties in international trade, and, accordingly, each Member shall take whatever action may be appropriate and feasible to eliminate such conditions within its territory." Such a labor standards-related provision was not included in the GATT, since it has been one of the most confrontational issues between developed and developing countries. It is quite interesting that note 14 of the Antidumping Code of the WTO expresses the possibility of social dumping.

Fourth, the authorities' political considerations may suspend investigations of antidumping duties against the transition economies. In the United States, for instance, section 734 of the Tariff Act gives the DOC great flexibility in dealing with non-market economies through suspension agreements. The DOC may suspend an investigation upon acceptance of an agreement with a nonmarket economy country if three factors are met: (1) the agreement is in the public interest, (2) the agreement can be effectively monitored, and (3) the agreement prevents the suppression or undercutting of price levels of domestic products by imports of the merchandise under investigation. Among others, the 'public interest' in the determination of suspending an investigation needs subjective judgment of the authorities. The DOC has increasingly utilized suspension agreements to settle antidumping cases with nonmarket economies.

Because the statute does not require approval of the agreement by, or even consultation with, the petitioning U.S. industry, the DOC's flexibility in using suspension agreements is even greater. Thus, the DOC has been given the flexibility by statute to deal with difficult political and economic issues through suspension agreements (Laroski, 1999). Thereby, consideration of political factors may influence the decision on antidumping measures against the transition economies, even if it may not influence the initiations of investigations.

The institutional characteristics of antidumping duties explained thus far show that considerations of social or political aspects can influence the protectionist pressures and protectionism against the transition economies. Whether such aspects are actually considered or not needs to be examined empirically.

\section{The model}

Takacs (1981), Finger et al. (1982), Moore (1992), Baldwin and Steagall (1994), Hansen and Prusa (1996), Leidy (1997), Mah (2000a, 2000b), Lee and Mah (2003), and Prusa (2006), among others, examined the impact of the domestic and international economic variables on protectionist pressures or protectionism empirically. Takacs (1981) revealed the macroeconomic determinants of the number of requests for safeguard investigations or proportion of successful safeguard cases in the United States. Finger et al. (1982) tried to reveal the influence of domestic politics and economic variables in antidumping and countervailing duties cases.

Moore (1992) examined the impact of the factors appearing in the antidumping laws on antidumping decisions. Baldwin and Steagall (1994) examined the decisions regarding antidumping and 
countervailing duties by probit. Hansen and Prusa (1996) examined whether the cumulation proviso introduced in the 1984 Trade Act was of significance in the antidumping injury determination. Estimating all equations in first differences, Leidy (1997) showed that the number of antidumping /countervailing duties petitions responded to the state of domestic macroeconomic activity but not to international economic factors. Mah (2000a) examined whether macroeconomic variables influence the injury decisions of the United States against the products exported from northeast Asian developing economies. Using the cointegration analysis, Mah (2000b) revealed that there exists a long run equilibrium relationship between the United States' injury determinations and macroeconomic variables. Lee and Mah (2003) examined whether changes in international trade regulations gave rise to changes in the probability of affirmative injury decisions relating to antidumping duties. Using probit estimation method, Mah (2006) tried to reveal the microeconomic determinants of antidumping duties in the United States. Prusa (2006) revealed that with respect to antidumping duties East Asia is definitely treated differently than all other parts of the world, using macroeconomic variables as the determinants of the antidumping duties.

Any of the previous literature, however, did not fully consider the social and political issues such as social dumping and political freedom as the determinants of the protectionist pressures and protectionism. Although Evenett and Vermulst (2005) points out the possibility of diplomatic considerations in the decisions on antidumping duties, they did not pursue empirical works. Neither did they focus on the transition economies. Considerations of the social and political issues may be more evident in investigations and impositions of antidumping duties against the transition economies due to the institutional characteristics explained in the previous section. Nielsen and Rutkowski (2005) dealt with the case of the European Union's antidumping policies towards the transition economies; meanwhile, they did not consider the institutional characteristics of those.

The current paper regards the investigations initiated and decisions of antidumping duties against the transition economies as the protectionist pressures and protectionism against them, respectively, and reveals their determinants. For them, export values would be noteworthy in the sense that the countries with higher export values are likely to face more frequent investigations and impositions of antidumping duties. Besides export values, social and political factors such as labor standards and the degrees of political freedom could also be considered as the determinants of investigations and impositions of antidumping duties. Therefore, the following equation is considered for estimation:

$$
A D P_{i}=b_{0}+b_{1} E_{X P O_{i}}+b_{2} \text { LABSTA }_{i}+b_{3} \text { POFR }_{i}+V_{i}
$$

where $\mathrm{ADP}_{\mathrm{i}}$ is defined as the number of investigation or imposition of antidumping duties against country i. EXPO denotes export values. LABSTA shows the number of core labor standards ratified by the concerned country. POFR stands for the degree of political freedom measured by the Freedom House Democraticness Index. V denotes the conventionally assumed disturbance term.

Ever since late 1998, producers from two most important transition economies, i.e. China and Russia, and since 2000, those from Kazakstan, Ukraine and Vietnam, and 'any non-market economy which is a member of the WTO' have been formally treated as equally as market 
economies (Nielsen and Rutkowski, 2005). Therefore, to confirm the peculiarities of the transition economies and to guarantee appropriate number of observations, data set for twenty seven transition economies during the period 1995-199 and that for twenty-nine transition economies during 2002-2006 are compared. Data for antidumping duties are taken from the WTO (http:// www.wto.org), which denote the number of investigations or impositions of antidumping duties for the concerned periods, the second half of 1995 - the first half of 1996 and the second half of 2002 - the first half of 2006. Export values which are measured in US\$ billions represent those summed for the period 1995 - 1998 and 2002 - 2005. Data for most of them are taken from the World Bank, World Development Indicators 1999, 2004 - 2007; while those for Tajikistan, Turkmenistan, Mongolia, Uzbekistan, and Vietnam during the period 1995 - 1998 are drawn from the WTO, International Trade Statistics 2001. The hypothesized value of the coefficient of EXPO is $b_{1}>0$, meaning the higher number of investigations or impositions of antidumping duties against the transition economies with the higher values of their exports.

For labor standards which are defined as the norms and rules that govern working conditions and industrial relations, labor unions in the importing, especially developed, countries may request investigation of dumping with respect to products exported from countries with low labor standards, which can be referred to as social dumping. Although there are various kinds of labor standards stipulated in the ILO Conventions, certain ILO Conventions constitute the core international labor standards which are of critical importance to the relationship with international trade.

ILO Conventions 87 and 98 provide provisions on the freedom of association and the right to organize and collective bargaining, i.e. the right of workers to form organizations of their own choice and to negotiate freely their working conditions with their employers, respectively. Conventions 29 and 105 establish the prohibition of all forms of forced labor, in the form of slavery and compulsory labor. Convention 111 provides for non-discrimination in employment, i.e. the right to equal respect and treatment for all workers. OECD (1996) suggests the selection of these core labor standards based on the reason that they embody basic human rights. The number of core labor standards ratified as of december 1997 and december 2004, respectively, is taken from the ILO (http://www.ilo.org). ${ }^{1)}$ The hypothesized value of the coefficient of LABSTA is $b_{2}<0$, since the number of initiation and imposition of antidumping duties may increase with the lower labor standards.

The Freedom House Democraticness Index which is actually the simple average of the reported data for four years during the data period, i.e. 1995 - 1998 and 2002 - 2005, are drawn from the Freedom House (http://www. freedomhouse.org). ${ }^{2}$ The higher value denotes the less democratic political situation. In case that the government of the importing country tries to put pressure on democratizing the political system of the exporting transition economy by trade policy measures, the hypothesized value of the coefficient of POFR would be $b_{3}>0$.

\footnotetext{
${ }^{1}$ The results using the number of core labor standards ratified as of the neighboring year are not qualitatively different from that reported in the current paper.

${ }^{2}$ As of July 2008, the Freedom House reports the data for the situation of the concerned countries until 2005.
} 


\section{Empirical Evidence}

During the data period covering the second half of 1995 - the first half of 1999, some 213 investigations on antidumping duties were initiated against the transition economies, which shared 24 percent of the total. Two-thirds of such investigations initiated, i.e. 131 cases, actually resulted in imposition of antidumping duties, meaning that initiation of investigation per se puts protectionist pressures on the transition economies' exports. Meanwhile, during the data period of the second half of 2002 - the first half of 2006, some 266 investigations on antidumping duties were initiated against the transition economies, sharing 32 percent of the total. Those investigations led to actual imposition of definitive antidumping duties as many as 228 cases.

Table 1

Determinants of protectionist threats against the transition economies

\begin{tabular}{|c|c|c|c|c|}
\hline variables & 1995 - & $1999^{\mathrm{a})}$ & 2002 - & $2006^{b)}$ \\
\hline constant & $\begin{array}{c}6.720 \\
(1.625)\end{array}$ & $\begin{array}{l}-5.473^{*} \\
(-1.976)\end{array}$ & $\begin{array}{l}10.426^{*} \\
(1.770)\end{array}$ & $\begin{array}{l}-8.342^{* *} \\
(-2474)\end{array}$ \\
\hline EXPO & $\begin{array}{c}0.157^{* *} \\
(14.714)\end{array}$ & $\begin{array}{l}0.163^{* *} \\
(15.830)\end{array}$ & $\begin{array}{c}0.885^{* *} \\
(18.888)\end{array}$ & $\begin{array}{l}0.089^{* *} \\
(20.450)\end{array}$ \\
\hline LABSTA & $\begin{array}{l}-2.018^{* *} \\
(-2.143)\end{array}$ & & $\begin{array}{l}-3.174^{* *} \\
(-2.567)\end{array}$ & \\
\hline POFR & & $\begin{array}{c}1.005 \\
(1.671)\end{array}$ & & $\begin{array}{c}1.277 \\
(1.485)\end{array}$ \\
\hline Adjusted $\mathrm{R}^{2}$ & 0.917 & 0.912 & 0.951 & 0.943 \\
\hline F statistics & $144.999^{* *}$ & $135.116^{* *}$ & $271.224^{* *}$ & $232.986^{* *}$ \\
\hline
\end{tabular}

Note: The values within the parentheses below the estimated coefficients denote the calculated $\mathrm{t}$ - statistics.

a) number of observations $=27$

b) number of observations $=29$

$*$ : significant at 10 percent level of significance

$* *$ : significant at 5 percent level of significance

The OLS estimation results using the number of investigations of antidumping duties as the measure of protectionist pressures are shown in Table 1. In all cases presented here and virtually every variation of the estimated equations, the coefficients of the concerned variables show the expected signs. The calculated adjusted coefficient of determination are quite high, i.e. between 0.91 and 0.95 . The estimation results show that export value is obviously the most important 
determinant of the protectionist pressures. During the late 1990s, as export value increases as much as US\$ 6 billion, the number of investigations of antidumping duties tends to increase by one. For the period 2002 -2006, increase of export values as much as US\$ 11 - 12 billion is revealed to increase the number of investigations of antidumping duties by one.

Regarding the possibility of initiations of antidumping duties with respect to social dumping, LABSTA is revealed to be significant at 5 per cent level of significance. More precisely, as the number of ratification of core labor standards increases by one, it tends to decrease the number of investigations of antidumping duties against the concerned transition economy by two for the 1990s and by three for the period $2002-2006$. That is, it appears that the importing countries tend to initiate investigation of antidumping duties when they observe low labor standards in the transition economies. Such a tendency is revealed to have been strengthened for the past several years. For political freedom, POFR is revealed to be not significant at 10 percent level of significance. That is, the domestic industries and their representatives in the importing countries do not tend to initiate investigation of antidumping duties to promote democraticness of the transition economies. The results do not change qualitatively when we use the different data period.

Table 2

Determinants of protectionism against the transition economies

\begin{tabular}{|c|c|c|c|c|}
\hline Variables & 1995 - & $1999^{\mathrm{a})}$ & $2002-$ & $2006^{\mathrm{b})}$ \\
\hline Constant & $\begin{array}{c}3.531 \\
(1.145)\end{array}$ & $\begin{array}{l}-4.825^{* *} \\
(-2.419)\end{array}$ & $\begin{array}{c}4.555 \\
(1.233)\end{array}$ & $\begin{array}{l}-4.304^{* *} \\
(-2.148)\end{array}$ \\
\hline $\begin{array}{c}\text { EXPO } \\
\text { LABSTA }\end{array}$ & $\begin{array}{l}0.127^{* *} \\
(16.012) \\
-1.275^{*} \\
(-1.815)\end{array}$ & $\begin{array}{l}0.131^{* *} \\
(17.631)\end{array}$ & $\begin{array}{l}0.063^{* *} \\
(22.362) \\
-1.388^{*} \\
(-1.790)\end{array}$ & $\begin{array}{l}0.065^{* *} \\
(24.990)\end{array}$ \\
\hline POFR & & $\begin{array}{l}0.803^{*} \\
(1.855) \\
\end{array}$ & & $\begin{array}{c}0.754 \\
(1.475)\end{array}$ \\
\hline Adjusted $\mathrm{R}^{2}$ & 0.927 & 0.928 & 0.962 & 0.961 \\
\hline F statistics & $166.629^{* *}$ & $167.568^{* *}$ & $358.039^{* *}$ & $345.001^{* *}$ \\
\hline
\end{tabular}

Note: The values within the parentheses below the estimated coefficients denote the calculated $\mathrm{t}$ - statistics.

a) number of observations $=27$

b) number of observations $=29$

$*$ : significant at 10 percent level of significance

$* *$ : significant at 5 percent level of significance

The estimation results on the determinants of the number of impositions of antidumping duties are shown in Table 2. The OLS estimation results show that export value is obviously the most important determinant of protectionism. During the late 1990s, as export value increases as 
much as US\$ 8 billion, the number of impositions of antidumping duties tends to increase by one. For the period 2002 - 2006, increase of export values as much as about US\$ 16 billion is revealed to increase the number of actual imposition of antidumping duties against the concerned country by one. Regarding the possibility of imposing antidumping duties with respect to social dumping, LABSTA is revealed to be significant at 10 percent level of significance regardless of the period under consideration. The absolute value of the estimated coefficients of LABSTA in Table 2, i.e. about 1.3 to 1.4 , is somewhat smaller than that in Table 1. That is, there is weak evidence that increase in the number of ratification of core labor standards tends to decrease the number of impositions of antidumping duties. As the number of ratification of core labor standards increases by one, it tends to decrease the number of actual imposition of antidumping duties against the concerned country by 1.3 to 1.4. Regarding political freedom, as Laroski (1999) argued, it may influence the importing authority's decision on antidumping duties. The estimation result shows that POFR is significant during the late 1990s at 10 percent level of significance. That is, there is weak evidence that importing countries imposed antidumping duties when they observed lower democraticness, i.e. the higher Freedom House Democraticness Index during the early stage of transition. Meanwhile, as the concerned transition economies passed the early stage of transition, the authorities of the importing countries tend not to consider the political freedom in the determination of actual imposition of definitive antidumping duties against the transition economies.

\section{Conclusion}

Reflecting the decreased tariff rates through several multilateral trade negotiations, many countries have used antidumping duties as their trade protection measures. Investigations or impositions of antidumping duties against the transition economies may be substantially different from those against market economies in the sense that: normal values needed in calculating the margin of dumping may be different in case of the transition economies; defining the concerned transition economies as nonmarket economies may influence decisions on antidumping duties, which may also be influenced by political considerations; and there is a possibility of suspending investigations of antidumping duties against the transition economies by the authority's political consideration.

The protectionist pressures in the face of low labor standards in the exporting countries may be related to the so-called social dumping. Therefore, this paper reveals the social and political determinants of the protectionist pressures and protectionism against the transition economies using the number of investigations and impositions of antidumping duties as the relevant measures, respectively.

The empirical evidence shows that export value is the most important determinant of the protectionist pressures or protectionism against the transition economies. Besides export value, what is interesting is the possibility of the protectionist pressures against social dumping. This paper shows that as the core labor standards tend to be low, it is likely to be perceived as social dumping. Consequently, the protectionist pressures in the form of initiating investigations of 
antidumping duties tend to be strengthened against such exporting countries, although the protectionist tendencies with respect to social dumping are not so apparent in the actual impositions of antidumping duties. Regarding political freedom, there was weak evidence that the different degrees of democraticness in the transition economies influence the protectionism against them during the 1990s. Meanwhile, the effect of different degrees of political freedom on actual imposition of definitive antidumping duties is not found during the period 2002 - 2006, which may be due to the fact that the importing countries perceived that the concerned countries passed the early stage of transition in their economic system ${ }^{3}$.

\section{Acknowledgement}

I wish to express my sincere thanks to three anonymous referees for very helpful comments on the earlier version of this paper. However, of course, all remaining errors are entirely mine.

\section{References}

Baldwin, R. E. and J. W. Steagall. 1994. An analysis of ITC decisions in antidumping, countervailing duty and safeguard cases. Weltwirtschaftliches Archiv. 130: 290-308.

Evans, P. and J. Walsh. 1995. The EIU guide to world trade under the WTO, EIU: London.

Evenett, Simon J. and Edwin, Vermulst. 2005. The Politicization of EC Antidumping Policy: Member States, Their Votes and the European Commission. The World Economy. 28: 701-717.

Finger, J. M., H. K. Hall, and D. R. Nelson. 1982. The political economy of administered protection. American Economic Review. 72: 452-66.

Hansen, W. L. and T. J. Prusa. 1996. Cumulation and ITC decision-making: the sum of the parts is greater than the whole. Economic Inquiry. 34: 746-69.

Hansen, W. L. and T. J. Prusa. 1997. The Economics and Politics of Trade Policy: An Empirical Analysis of ITC Decision Making. Review of International Economics. 5: 230-245.

Kufuor, K. O. 1998. The Developing Countries and the Shaping of GATT/WTO Antidumping Law. Journal of World Trade. 32: 167-196.

Laroski, J. A. Jr. 1999. NMEs: A Love Story - Nonmarket and Market Economy Status under U.S. Antidumping Law. Law and Policy in International Business. 30: 369-398.

Lee, K. H. and J. S. Mah. 2003. Institutional Changes and Antidumping Decisions in the United States. Journal of Policy Modeling. 25: 555-565.

Leidy, M. P. 1997. Macroeconomic conditions and pressures for protection under antidumping and

3 This work was supported by the Ewha Womans University Research Grant of 2007 
countervailing duty laws: empirical evidence from the United States. IMF StaffPapers. 44: 132-44.

Mah, J. S. 2000a. The United States' antidumping decisions against the Northeast Asian dynamic economies. The World Economy. 23: 721-732.

Mah, J. S. 2000b. Antidumping decisions and macroeconomic variables in the USA. Applied Economics. 32: 1701-1709.

Mah, J. S. 2006. ITC Decisions on Antidumping Duties under the WTO. Applied Economics Letters. 13: 73-76.

Moore, M. O. 1992. Rules or politics? An empirical analysis of ITC anti-dumping decisions. Economic Injury. 30: 449-66.

OECD. 1996. Trade, Employment and Labor Standards, Paris.

Nielsen, Jorgen U. and Aleksander Rutkowski. 2005. The EU Anti-dumping Policy Towards Russia and China: Product Quality and the Choice of an Analogue Country. The World Economy. 28: 103-136.

Polouektov, A. 2002. Non-Market Economy Issues in the WTO Anti-Dumping Law and Accession Negotiations: Revival of a Two-tier Membership? Journal of World Trade. 36: $1-37$.

Prusa, Thomas J. 2006. East Asia's Anti-dumping Problem. The World Economy. 29: 743-761.

Takacs, W. E. 1981. Pressures for protectionism: an empirical analysis. Economic Inquiry. 19: 8793. 
